\title{
000.3417 .30
}

Terminal Progress Report for Research Carried out Under

AEC Contract AT(11-1)-3417

March 1, 1967 - March 1, 1972)

"Hypothalamic Control of

Pituitary Gland Function"

by

W. C. Hymer

Biology Department

Pennsylvania State University

University Park, PA 16802

ALSB 


\section{DISCLAIMER}

This report was prepared as an account of work sponsored by an agency of the United States Government. Neither the United States Government nor any agency Thereof, nor any of their employees, makes any warranty, express or implied, or assumes any legal liability or responsibility for the accuracy, completeness, or usefulness of any information, apparatus, product, or process disclosed, or represents that its use would not infringe privately owned rights. Reference herein to any specific commercial product, process, or service by trade name, trademark, manufacturer, or otherwise does not necessarily constitute or imply its endorsement, recommendation, or favoring by the United States Government or any agency thereof. The views and opinions of authors expressed herein do not necessarily state or reflect those of the United States Government or any agency thereof. 


\section{DISCLAIMER}

Portions of this document may be illegible in electronic image products. Images are produced from the best available original document. 
Statement of Problem

Since the pioneering work of Schally in the late 1950's, it has become abundantly clear that the hypothalamus is intimately involved in the regulation of adenohypophysial cell. function. Numerous books, review articles, etc., are now available which spell out, in detail, what is currently known about these regulatory mechanisms. Briefly stated, different peptides (synthesized in hypothalamic nuclei) reach the different types of pituitary cells by way of the portal vessel circulation. Once in contact with the pituitary cell membrane, a series of events occur within the cell to effect release of hormone. This regulation is amazingly specific; i.e. each hormone-producing cell type is under control of a single hypothalamic factor (hereafter referred to as releasing factor). The only apparent exception to this specificity is that of the gonadotropin releasing factor. In this case it appears that a single decapeptide controls the release of both FSH and IH.

Two of the releasing factors have now been chemically synthesized and are currently commercially available for testing. One factor, which controls the secretion of TSH, is a tripeptide. The other, which controls secretion of FSH and LH, is a decapeptide. The structure of the other releasing factors is unknown at present. The fact that these synthetic preparations are active in humans as well as laboratory animals raises many clinically significant questions; some of which center on possible new means of birth control. For a background review to this entire problem, the reader is referred to a chapter I wrote for the new edition of Best and Taylor's "Physiological Basis of Medical Practice", scheduled for publication this year (8). It was enclosed in last years' AEC progress report as document 
$\operatorname{AT}(11-1)-3417-17$

In addition to the now extensive literature on releasing factors, the isolation and synthesis of pure pituitary hormones continues to be a major goal in many different laboratories: The work which we have carried out during the past 5 years under AEC support falls somewhere between those biochemical efforts indicated above, and their ultimate medical applications. Throughout the past five years, the overriding theme to our research efforts has been that of defining the sequence of intracellular events which occur in a pituitary cell after it is stimulated to release hormone. Our basic research goals were as follows:

1) to develop techniques for the separation and isolation of different pituitary cell types.

2) to study effects of hypothalamic extracts on translational and transcriptional control in the in vitro pituitary gland.

3) to investigate the problem of cell turnover in the pituitary gland. Our feelings were (and still are) that any information gained from these experimental approaches would be helpful in understanding some of the mechanisms involved in the synthesis and release of the pituitary hormones. Those, in turn, relate to the complex physiological "loops" which ultimately assure proper. function of the entire hypothalamo-hypophysial axis. . 
Research Goal \#1: Separation of Different Pituitary Cell Types.

For over 70 years, the mammalian adenohypophysis has been largely studied using either the histological or physiological approach. In the histological approach, cells which stain differently due to their hormone contents have been described, counted and photographed after different endocrinological manipulations. (For example, the fact that castration changes a specific type of. blue-staining cell provided circumstantial evidence that that cell was involved in the production of gonadotropin). While this approach served a useful purpose, its limitations have been realized in more recent years. In the second (i.e. "physiological") approach, hormone contents were measured after similar treatments. Studies in which both approaches are used have been rare indeed.

Some three years ago it became clear to us that a meaningful study of intracellular events occuring in a pituitary cell in response to stimulation by hypothalamic releasing factor would require homogenous populations of the different cell types. Accordingly we set out to develop and adapt existing cell separation methods to pituitary tissue. As might be imagined, this has proven to be a very difficult problem. However, we are encouraged by our progress to date. Much of this progress is to be found in the manuscript enclosed with this final report entitled "Enrichment of Cell Types from the Rat Adenohypophysis by Sedimentation at Unit Gravity" (7). This manuscript has passed initial review for publication in Endocrinology and a revised copy (the one submitted) is currently. under consideration. The method for cell dissociation ( $\mathrm{pg} .5$ of the manuscript) yields approximately $70 \%$ of the cells that make up the adenohypophysis. The description of the unit gravity cell separation method is currently done as described in this 
manuscript. With this method we can now obtain cell fractions which contain over $65 \%$ somatotrophs; the primary contaminating cell type being the basophil. We currently use a second centrifugation step to separate the basophils from the somatotrophs. This involves centrifugation of the cells in the somatotroph fraction (see above) in a linear gradient of concentrated (14-28\%) bovine serum albumin (BSA). Under these conditions we have discovered that the basophils band at density $1.060 \pm .0007 \mathrm{~g} / \mathrm{cm}^{3}$; while the somatotrophs are more dense and band at $1.075 \pm .0007 \mathrm{~g} / \mathrm{cm}^{3}$. With these 2 procedures, the second of which I developed on my sabbatical leave in Canada this year, we can now routinely obtain cell fractions which consist of over $90 \%$ somatotrophs. These results were presented at the American Federation meetings in April 1972 (19).

Once the method for the isolation of the somatotrophs was developed, we carried out a number of preliminary studies on these isolated cells. Most of the results from these studies have been presented in abstract form. Ultrastructure. It was important to determine the appearance of these cells at the electron microscope level. Our results clearly show that the cells retain excellent ultrastructural-integrity after separation. Shown in Fig. 1 is the appearance of the isolated cells, at the light microscope level. Their appearance at the electron microscope level is shown in Fig. 2. The isolated cells can be incubated for 3 hours and their structure is virtually identical with that of the comparable cell type in situ. These results were recently presented at the Candaian Federation Meetings in Quebec City (20). Growth hormone content. Using a specific radioimmunoassay procedure for rat growth hormone, we have determined that the isolated somatotrophs retain growth hormone. Concentration of growth hormone in the original cell suspension is 30-40 nanograms/1000 cells. In fractions from the somatotroph region of 


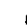
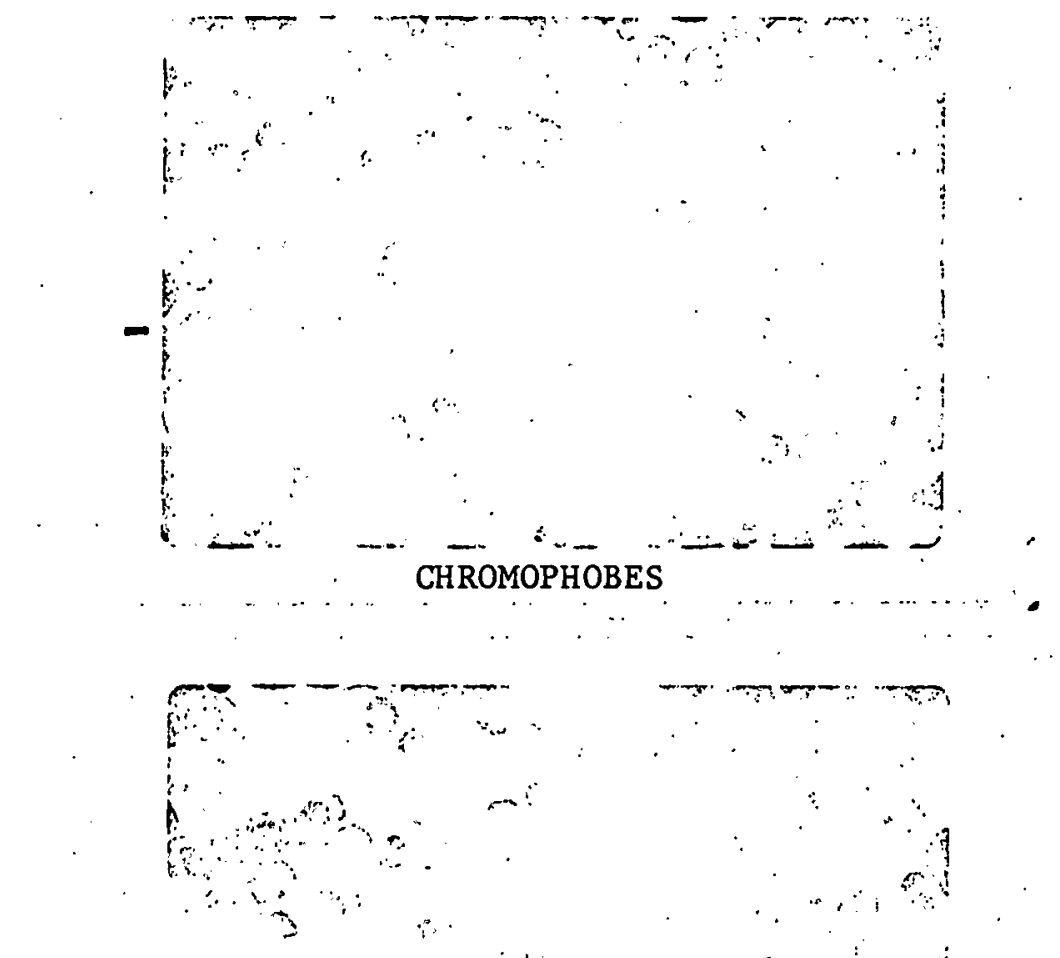

4.

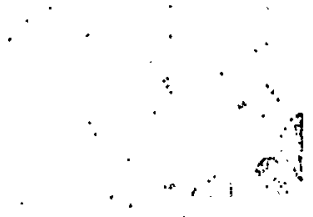

o

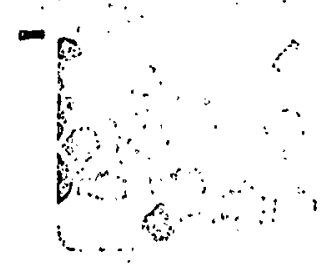

SOMATOTROPHS

Fig. 1

Appearance of isolated cells in the a) chromophobe and b) somatotroph fractions. $\times 430$. 

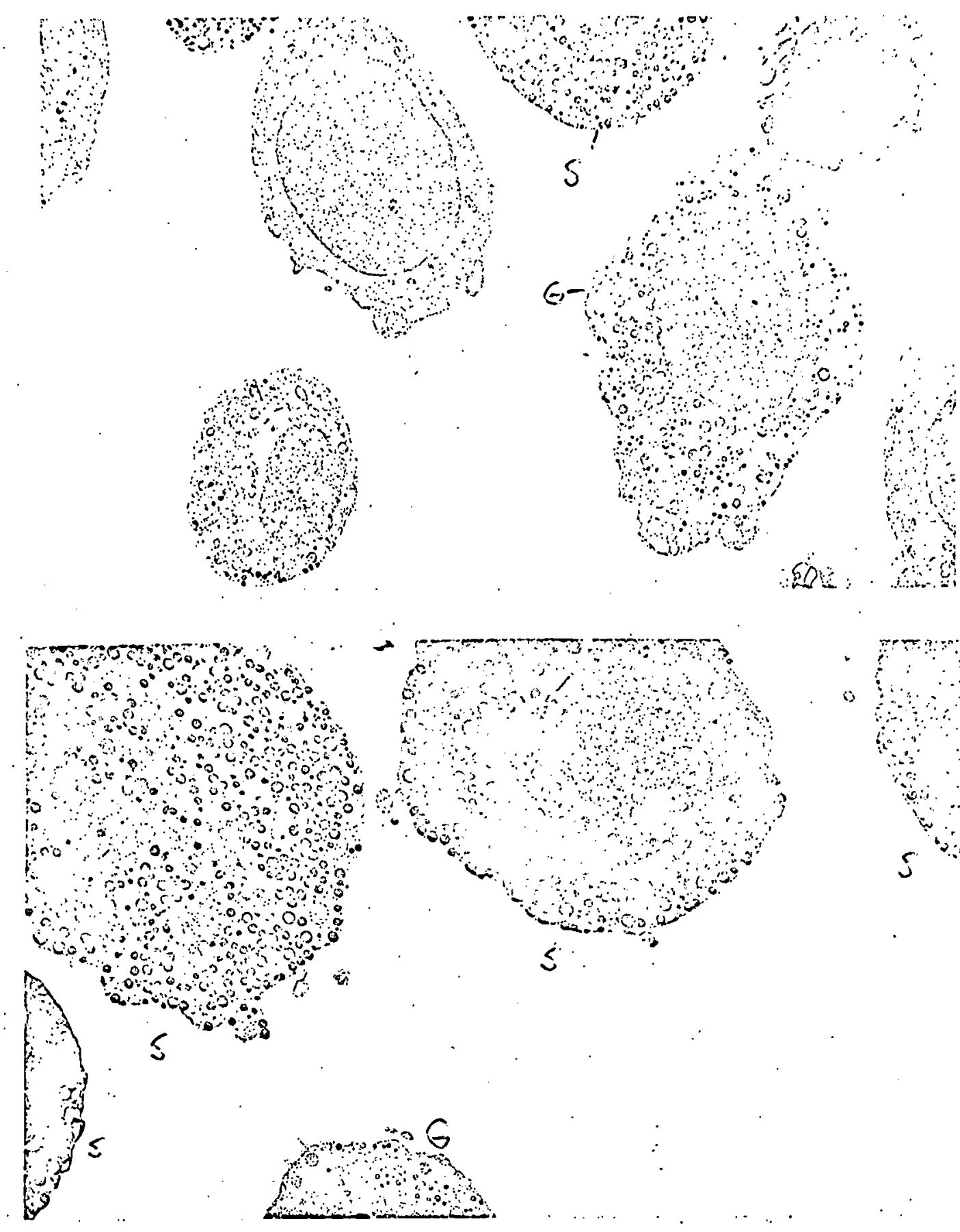

Fig. 2

Appearance of cells in the original suspension (top) and $70 \%$ somatotroph fraction (bottom). Cells are identified on the basis of secretion granule size. $S=$ somatotroph. $G=$ gonadotroph: 
the cell separation gradient, growth hormone levels approaches 250 nanograms/ 1000 cells. These results will be presented at the fall meetings of the American Physiological Society (21). Effect of Dibutyryl Cyclic AMP (DCAMP). Cyclic AMP, the so-called "second messenger," has been shown to be effective in promoting release of hormone from the in vitro pituitary. We used the dibutyryl derivative of this cyclic nucleotide to measure its effects on a) release of growth hormone from isolated somatogrophs and b) levels of protein synthesis in these same cells. We were able to show that this compound doubled release of immunoassayable growth hormone after incubation with isolated somatotroph for 1 hour. Under similar conditions; however, incorporation of ${ }^{14} \mathrm{C}$-amino acid into TCA precipitable protein was significantly decreased. These results suggest that a dichotomy may exist between synthesis and release mechanisms, but the study must be extended to include different concentrations of DCAMP. Such experiments are planned for the near future. Many of these results were presented at the Canadian Physiology Meetings last winter (18). Effects of growth hormone releasing factor (GRF). It was of considerable interest to evaluate the secretory response of the isolated somatotroph to the physiological secretogogue GRF. While in Canada we obtained a highly purified preparation of GRF from Dr. S. M. McCann and his group in Texas. We first evaluated the ability of this compound to promote release of growth hormone from the in vitro pituitary. In three separate experiments we then used concentrations of 16, 50 and 100 microliters of this material to test its effectiveness in causing release of growth hormone from the isolated somatotrophs. The samples from these experiments are in the freezer waiting to be assayed. If positive results are obtained, we feel that this could well be the ideal model to use in future studies investigating intracellular mechanisms of hormone release. I will continue to collaborate with $\mathrm{Dr} \cdot$ Kraicer in this exciting area of research. 
Summary. We have developed, over the past three years, methods to isolate somatotrophs from the rat adenohypophysis in purity greater than $90 \%$. These isolated cells appear to maintain their viability by all criteria thus far used, viz. light and electron microscopy, dye exclusion tests, RNA and protein biosynthetic capacities, growth hormone content and finally release of hormone in response to a number of secretagogues. We are confident that the isolated somatotrophs will offer a new (and theoretically ideal) model in which to study mechanisms involved in the synthesis and release of pituitary hormone. 
Research Goal \#2: Effects of hypothalamic extracts on translational and transcriptional control in the in vitro pituitary gland.

In vitro Incubation Method. The system that we have used to monitor the effects of hypothalamic extracts (HE) on a number of intracellular events in the pituitary is virtually identical to the one used by all other workers in the field. It has been known' for the last 10-15 years that addition of crude acid extracts of fresh rat hypothalamic tissue to anterior pituitary glands maintained in vitro will cause significant release of all pituitary hormones (except prolactin) into the incubation medium. This simple technique has provided a major portion of the experimental evidence for the existence of the releasing factor molecules. In all of our experimental work, hypothalamic extracts (HE) have been prepared from fresh hypothalami by homogenization in $0.1 \mathrm{NHC} 1$, centrifugation, neutralization of the clear supernatant and subsequent use in the incubation system. This system involves incubation of single (or half) pituitary glands in $1.5 \mathrm{ml}$ of Medium 199 or Krebs-Ringer bicarbonate buffer, both maintained at $\mathrm{pH}$ 7.3-7.4 by incubation at 37C in a Dubnoff Metabolic Shaker with constant gasing to provide an atmosphere of $95 \% \mathrm{O}_{2}$ and $5 \% \mathrm{CO}_{2}$. Controls for these experiments utilize an identical extraction procedure on fresh cerebral cortical tissue (CE). Using this system, a number of interesting findings relating to the phenomenon of hormone release have emerged from numerous laboratories over the last ten year period. Some of the more important are a) over a certain limited range, hormone release is related to dose of $\mathrm{HE}$; b) there is an absolute requirement for $\mathrm{Ca}^{++}$in the incubation medium, release will not occur under conditions where $\left[\mathrm{Ca}^{++}\right]$is low (e.g. EGTA); c) elevation of $\mathrm{K}^{+}$to 5 times its normal physiological concentration 
(i.e. $30 \mathrm{mM}$ ) in the incubation medium will cause hormone release (presumably making the cell membranes "leaking") and d) addition of low concentrations of dibutyryl cyclic AMP (DCAMP) to the medium causes significant hormone release. From these observations, the following current working hypothesis on the mechanism of releasing factor action has emerged: a releaser binds to a receptor site on the target cell membrane. Adenyl cyclase is closely linked to this receptor site. Binding of the releaser promotes activation of the cyclase system which leads to increased levels of cyclic AMP; this in turn promotes activation of several protein kinases. It is not yet clear what proteins are phosphorylated by this enzyme; some may be of the ribosomal variety, others may be in the stored hormone. By mechanisms which are as yet undefined (perhaps through contraction of microtubular elements), secretory granules undergo exocytotic processes leading to hormone release. While much of this work has recently emerged from Labrie's laboratory (see e.g. J. Biol. Chem. Dec. 1971); the above scheme by no means represents the entire story.

Especially unclear are questions relating to synthesis of new hormone, or activation of a "prohormone" form after stimulation by HE. The work described in the section of the report deals largely with questions relating to this particular point. Our basic approach has been that of adding labeled precursor amino acids (e.g. $\mathrm{c}^{14}$-leucine) to the incubation medium; allowing incorporation to proceed (i.e. uptake of label into the gland as well as incorporation into a TCA-precipitable protein or hormone); and an estimation of the effect of $\mathrm{HE}$ on hormone synthesis (usually evaluated by polyacrylamide gel electrophoresis). The kinds of responses that we have obtained are briefly discussed in the following sections. 
Effects of $\mathrm{HE}$ on General Intracellulax Metabolic Events

$\underline{0}_{2}$ consumption. It has been shown by several investigators that the HEinduced release of hormone from pituitaries incubated in the presence of respiratory and/or metabolic inhibitors is completely blocked by these agents. A number of years ago we measured the rate of $\mathrm{O}_{2}$ consumption by pituitary halves incubated in medium containing $\mathrm{HE}$ or $\mathrm{CE}$. In four separate experiments the respiratory rate in $\mathrm{HE}-t$ reated glands was significantly higher than the corresponding control tissues treated with $\mathrm{CE}$ or neutralized $\mathrm{HCl}$ (Graph 1). Although this result was not published, it is of interest because it shows that a general parameter of metabolic activity, viz. $\mathrm{O}_{2}$ consumption, is increased when pituitary cells are stimulated to release hormone. With the availability of purified somatotrophs, it would be of interest to repeat these experiments.

RNA synthesis. About the time this contract began, it was generally believed that many hormones acted, as a primary event, through activation of transcriptive mechanisms within the nucleus of the target cell. Accordingly, we studied the characteristics of RNA metabolism in the incubated pituitary, especially after stimulation by $\mathrm{HE}$. Although we were able to show that a) RNA synthesis was taking place in the tissue and b) new ribosomes were being made during the 4 hours incubation, we were unable to find any alteration in the rate of RNA synthesis after administration of $H E$ in vitro or in vivo. These results, which were published in 1967 (1), strongly indicated that formation.. of new RNA molecules were not required for releasing factor action. Since 1967 the results of other investigators would argue in favor of this generalization. 


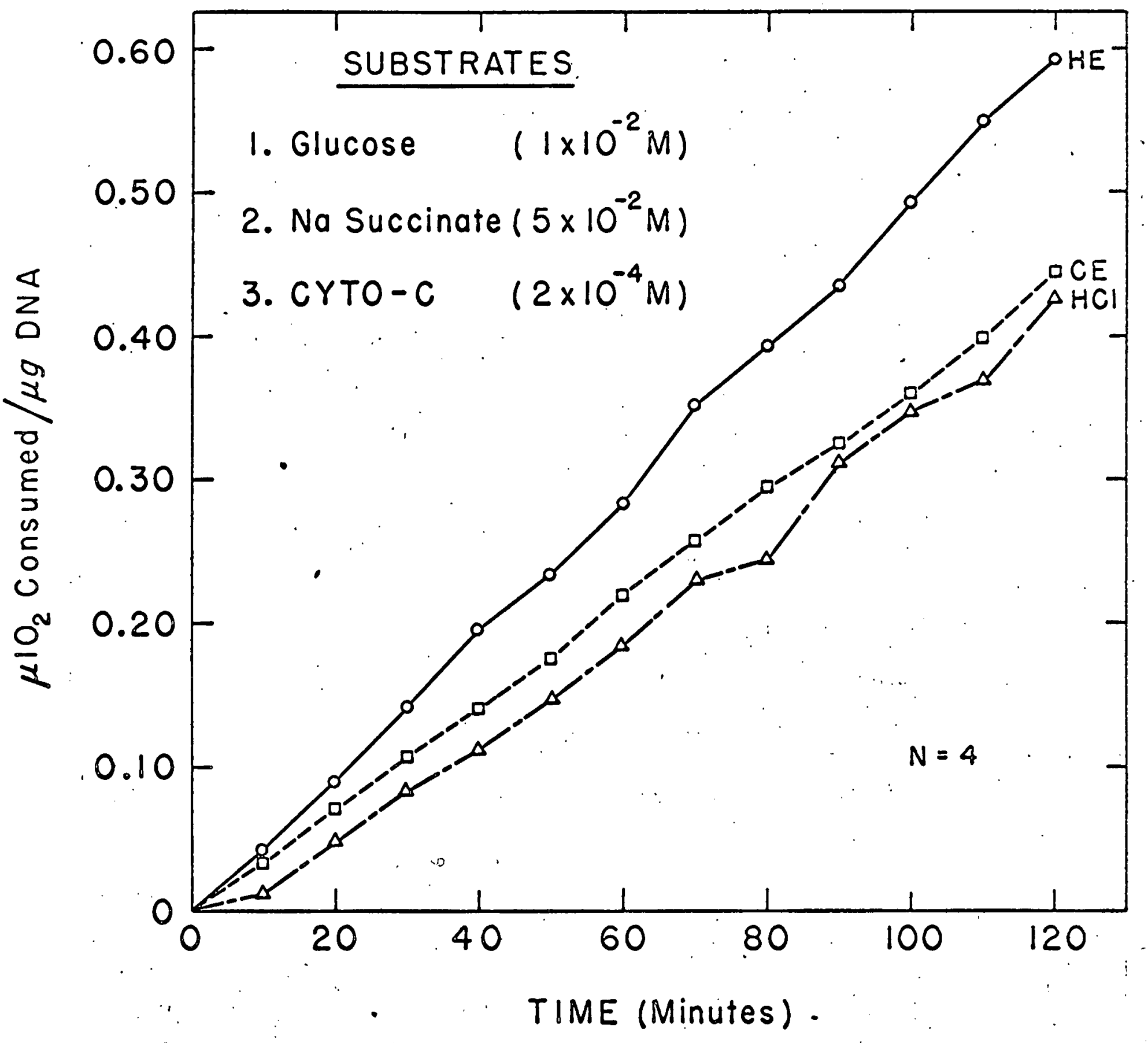


General Protein Synthesis. After these RNA studies were completed, we turned our attention to another possible site of releasing factor action, viz. translational control at the polyribosome level. About this time many people were becoming interested in this question, and many techniques were initiated to evaluate synthesis of new hormone after stimulation by $\mathrm{HE}$. These included a) assessment of hormone content within the gland after HE-treatment b) measurement of radioactivity in bands recovered from polyacrylamide gels which were purported to contain hormone or c) measurements of radioactivity in precipitates formed after treatment of tissue extracts with antisera to specific hormones. The technical problems associated with and subject to numerous limitations. For example, the complex cellular nature of the gland; the numerous possible molecular forms that any given hormone may assume; the generation of specific antibodies to these hormones, have to date made progress limited in this area. At the time of writing this report, the answers still are by no means complete.

We began our protein synthesis work by measuring incorporation of ${ }^{14} \mathrm{C}$-ámino acid precursors to total TCA-precipitable pituitary protein after $\mathrm{HE}$ or CE treatment. Our initial results suggested that some protein(s) was made in response to HE-stimulation, and that it could be recovered in the incubation medium (i.e. it was released) as early as 1 hour after addition of releasing factor. Moreover, in these early studies, we also examined polyribosome profiles after similar treatments. The results of these early studies, which were published in 1968 (3), encouraged us to pursue this question utilizing the gel electrophoresis technique to assess synthesis of specific hormones after treatment of pituitaries with releasing factors. These studies are summarized in the next section. 
Effects of $\mathrm{HE}$ on Synthesis of Specific Pituitary Hormones.

Over the past three years, my graduate students have studied patterns of hormone synthesis after numerous physiological treatments. Specifically, they have examined a) synthesis of follicle stimulating hormone (FSH) after treatment with HE (Mr. John Davis); b) synthesis of growth hormone (GH) in pituitaries from thyroidectomized rats (Mr. Ed Augustine) and c) the effects of divalent catious and DCAMP on GH synthesis (Mr. Gary Snyder). In these studies the polyacrylamide gel electrophoretic method has been used to assess hormone biosynthetic levels. In each case, the validation of the assay method was accomplished by the isolation of hormone-specific secretory granules; electrophoresis of the proteins contained within these granules; extraction of hormones from gel slices and bioassay of the extracts to localize hormone on the gel. I believe that these procedures, while difficult and time-consuming, are crucial to any meaningful study involving hormone biosynthesis. As indicated below, each of these studies is in a slightly different stage of completion. Included with this final report are either manuscripts about to be submitted for publication or drafts of thesis material. I. FSH biosynthesis: effects of castration and HE treatment. In the initial. phases of this study, it was observed that the HE prepared from male rats castrated for 1 week stimulated incorporation of amino acids into a) the acid soluble pools and b) the TCA-precipitable protein fraction of pituitaries from these animals. After localization of FSH on the polyacrylamide gel (protein with an $\mathrm{R}_{\mathrm{f}} .614$ ), Mr. Davis examined FSH biosynthesis rates after these same treatments. A sma11, but consistent increase in FSH synthesis rates was observed in glands coincubated with HE. These data were presented at the AIBS meetings two years ago (13). and provide the basis for the working 
manuscript enclosed with this report. It will be submitted for publication within the next several months (23).

In any study involving hormone synthesis, it is important to monitor release of newly synthesized hormone into the incubation medium. About a year and one-half ago Mr. Davis found considerable bioassayable FSH activity in media from glands incubated in the presence of $\mathrm{HE}$ (thereby showing that the extract did indeed possess releasing factor activity). In order to evaluate the proportion of newly synthesized FSH in the preparation, the incubation media were also electrophoresed; the gel subsequently divided and FSH bioassays carried out in each fraction. Surprisingly, no activity could be recovered from the gel! In an attempt to.explain this curious result, FSH from the gland or incubation media has been characterized in a number of different ways. Included among these are a) chromatography on Sephadex G-100; b) sedimentation analysis on linear sucrose gradients and c) immunoreactivity (to an antibody generated against ovine FSH) as measured by Ouchterlony diffusion tests. The results from each of these characterization studies all strongly indicate that during (or after) the secretion process, there is a change in the configuration of the hormone molecule which renders it unstable to electrophoresis.

Finally, Mr. Davis has also studied the effects of different doses of HE or DCAMP on intracellular FSH synthesis. His results show that over certain critical concentrations, both compounds will stimulate incorporation of amino acids into FSH. These results are to be found in the Results section of Mr. Davis' Ph.D. thesis which is enclosed with this progress report (23). 
II. GH biosynthesis: effects of thyroidectomy.

It has been known for many years that the number of stainable growth hormone producing cells in the pituitary gland is drastically diminished after. thyroidectomy. On the basis of this observation Mr. Augustine has measured GH biosynthesis 1 to 3 weeks after thyroidectomy. (The validation of the GH-polyacrylamide gel assay technique is briefly described in the next section). After this operation, incorporation of amino acids into the $\mathrm{GH}$ band is reduced by $56,66,75 \% ; 1,2$, and 3 weeks after the operation. In a long-series of experiments, the effect of a single injection of thyroxine (T4) to the thyroidectomized animal 12-36 hours prior to sacrifice. has been examined. With this simple treatment, $\mathrm{GH}$ synthesis is stimulated $125 \%$ over the control value at 36 hours after injection. Exactly comparable studies have been carried out to estimate levels of RNA synthesis after similar hormone treatment. In general the results parallel those just described for growth hormone synthesis and might suggest that synthesis of new RNA molecules is prerequisite for synthesis of new $\mathrm{GH}$. To investigate this possibility, Actinomycin $\mathrm{D}$ is being administered with $\mathrm{T} 4$ prior to killing the animal. These results form the basis of Mr. Augustine's Ph.D'. thesis.

A manuscript describing some of Mr. Augustine's earlier results on the development of an assay for pituitary RNA polymerase is also included with this report (24).

III. GH Synthesis: effects of divalent catious and DCAMP.

It is now universally accepted that $\mathrm{Ca}^{++}$is somehow involved in the process of hormone release. In situations where $\mathrm{Ca}+$ is removed from the incubation medium (either by preparation of a $\mathrm{Ca}^{++}$-depleted medium or addition of EGTA), HE will not stimulate'hormone release. We have therefore attempted 
to measure $\mathrm{GH}$ synthesis in tissue incubating in $\mathrm{Ca}^{+{ }^{+}}$-depleted medium. The results of these studies are taken from the work of Mr. Gary Snyder. A working draft of Mr. Synder's masters degree thesis is included with this report (25). The results of his efforts are briefly summarized below. Synthesis of total pitultary protein is somewhat increased in pituitaries incubated in a $\mathrm{Ca}^{++}$-free Hanks balanced salt solution (HBSS). Addition of $5 \mathrm{mM}$ DCAMP initially decreases incorporation in the HBSS-control glands, but has relatively little effect on:synthesis in glands incubated In $\mathrm{Ca}^{+}$depleted media.

To determine the effects of these same treatments on synthesis of $\mathrm{GH}$, a polyacrylamide gel electrophoretic assay method was developed utilizing partially purified GH secretion granules as the starting point (see manuscript). A protein, with electrophoretic mobility of .43 was found to contain significant biologically active $\mathrm{GH}$.

As before, synthesis of $\mathrm{GH}$ was somewhat lower in glands incubated with DCAMP. However, when glands were incubated in a $\mathrm{Ca}^{++}-\mathrm{Mg}^{+}$depleted media, DCAMP apparently stimulated GH synthesis after 4 hours of incubation. These data offer suggestive evidence that. under conditions where release is blocked, GH synthesis may be stimulated.

Mr. Snyder has also studied the stability of $\mathrm{GH}$ secretory granules isolated from tissues previously incubated in $\mathrm{Ca}^{+}+$-depleted media. It is of interest that incubation of tissue in ion-depleted media renders the secretory granule in a form where it is readily solubilized for gel electrophoresis. Granules isolated from glands incubated in the "normal" ionic environment, however, require treatment with a strong non-ionic detergent (e.g. Triton $\mathrm{X}-100)$ to render the growth hormone in a form which will 
migrate on the acrylamide gel. Mr. Snyder has presented these findings at the AIBS meetings last winter (17).

Summary. From the studies outlined in this section, it should be obvious that a positive relationship between $\mathrm{HE}$ and hormone synthesis has not, as yet, been firmly established. Our studies do show however, that small but significant increases in synthesis of both FSH and $\mathrm{GH}$ can be shown to place after addition of either HE or DCAMP to the incubation medium.

The system used to evaluate hormone synthesis is certainly complex. The extreme cellular heterogenity of the gland, as well as the numerous physiologically active compounds in HE, contribute to this complexity. In future work on this problem we will use isolated pituitary cells and synthetic releasing factors as they become avallable for testing. 
Research Goal \#3: Cell Turnover in the Pitu1tary Gland.

Until a few years ago, it had been assumed by most endocrinologists that little if any cell turnover occured in the pituitary of the adult animal. Turnover which did take place was believed to occur in undifferentiated "blast" cells; cells producing hormone were not capable of division. I was therefore surprised to find, in some early experiments I did in 1967, considerable uptake of $\mathrm{H}^{3}$-thymidine into the DNA fraction of pituitaries incubated in vitro. During the next 4 year period, many experiments were done to elucidate a). the classes of cells involved in turnover and b) the role that hormones, enzymes, or environmental influences might play in regulation of turnover. A majority of this work was done by Andrea Mastro.

Characterization of system. In our initial study we showed that $1-2 \%$ of the pituitary cell s in young adult rats were actively synthesizing DNA. Labeled mitotic figures were found in cells synthesizing $\mathrm{GH}$, gonadotropins, etc., as well as in the classic "chromophic" cell. Data collected from microspectrophotometric and blochemical extraction procedures clearly showed that uptake reflected cell turnover, and not. some metabolic component of the DNA molecule. These results were published in 1969 (4). Later that same year Miss Mastro confirmed some of these results using the technique of electron microscopic radioautography (5).

Hormonal and environmental influences on pituitary cell turnover. With the assay method fust described, we assessed levels of DNA synthesis in pituitaries of castrated animals. We found that incorporation of $3 \mathrm{H}-$ thymidine into the DNA of pituitaries from castrate rats increased significantly 5 days after the operation; and that this increase was maintained, relative to sham-operated controls of the same age, over the entire period of castration ( 4 weeks). We also noted a $3 x$ increase in the percentage of labeled 
basophils 1 month after castration. This result, which was published in 1970 (6), closely reflected physiologically induced mitotic activity in a specific class of pituitary cells. In this same paper, those results were further extended by the interesting observation that the time (and length) of exposure of the animal to light modified the DNA synthetic response. These findings led us to speculate that cell turnover in the pituitary was controlled not only by specific levels of circulating hormone, but by as yet unspecified neuroendocrine mechanisms.

DNA polymerase in the pituitary. In an effort to pinpoint a possible Intracellular site for control of DNA synthesis, a system for the assay of DNA polymerase was developed by Miss Mastro for her Ph.D. thesis. Results from these studies have been submitted for publication, and the manuscript is enclosed with this report (22). Basically our results showed that activity of this enzyme decreased as the animals got older, but increased after treatment with estrogens. These changes in activity therefore paralleled those seen when DNA synthesis was monitored using

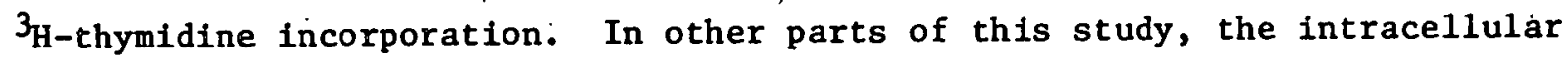
localization(s) of the enzyme were elucidated, and on the basis of the findings it was concluded that endogenous template, rather than enzymes, hormones, or other cofactors, were probably limiting DNA replication in the pituitary. 


\section{Students Trained on Project}

1. Dr. C. K. Grieshaber. Ph.D., Pennsylvania State University, 1969. Postdoctoral fellow, National Cancer Institute, NIH, 1969-1972. Current position: staff biologist NIH.

2. Dr. Andrea Mastro. M.S., Pennsylvania State University, 1969. Ph.D., Pennsylvanta State University, 1971. Current position: postdoctoral fellow in Dr. G. C. Mueller's laboratory, McArdle Laboratory for Cancer Research, University of Wisconsin, Madison.

3. Dr. John Davis. M.S., Pennsylvania State University, 1970: Ph.D., Pennsylvania State University, 1972. Current position: postdoctoral fellow in Dr. A. Schuetz's laboratory, Johns Hopkins Medical School, Baltimore, Maryland.

4. E. A. Augustine. Ph.D., Pennsylvania State University (November, 1972). Expected position: unknown at present.

5. G. Snyder. M.S., Pennsylvania State University, 1972. Current position: doctoral candidate in my laboratory.

Post-doctoral fellows in project: None: 


\section{Publications on Project}

A. Published articles or those "in press".

1. Hymer, W. C. and A. Stere; 1967. Effect of hypothalamic extracts on RNA synthesis in rat anterior pituitary tissue. Proc. Soc. Exp. Biol. and Med. 125(4):85-90.

2. Stere, A. and W. C. Hymer. 1967. Effect of hypoxia exposure on RNA synthesis in rat anterior pituitary in vitro." Penna. Acad. ScI. Vo1. 41. 1-5.

3. Grieshaber, C. K. and W. C. Hymer. 1968. Effect of hypothalamic extracts on protein synthesis in rat anterior pitultary tissue. Proc. Soc. Exp. Biol. \& Med. 128:459-463.

4. Mastro, A., W. C. Hymer and C. D. Therrien. 1969. DNA synthesis in adult rat anterior pituitary glands in organ culture. Exp. Ce11 Res. 54:407-414.

5. Mastro, A., E. Shelton and W. C. Hymer. 1969. DNA synthesis in the rat anterior pituitary: An. electron microscopic radioautographic study. J. Cell Biol. 43:626-629.

6. Hymer, W. C., A. Mastro and E. Griswold. 1970. DNA synthesis in the anterior pituitary of the male rat: Effect of castration and photoperiod. Science 167:1629-1631.

7. Hymer, W. C., W. H. Evans, J. Kraicer, A. Mastro, J. Davis and E. Griswold. Enrichment of Cell Types from the Rat Adenohypophysis by Sedimentation at Unit Gravity. Endocrinology, (in press).

8. Hymer, W. C. Chapter in Physiological Basis of Medical Practice Best and Taylor (Ninth Ed.). Regulation of the anterior pituitary. (in press).

\section{B. Abstracts}

9. Mastro, A., W. C. Hymer, and C. D. Therrien. 1968. DNA synthesis in adult rat anterior pituitary glands in organ culture. Biophysical Journ. 8, A-179.

10. Mastro, A., W. C. Hymer and C. D. Therrien. 1968.' DNA synthesis in adult rat anterior pituitary glands in organ culture. J. Cell Biol. $39(2): 85 a$.

11. Hymer, W. C.; Mastro and E. Griswold. 1969. DNA synthesis in the rat anterior pituitary: Effect of castration and photoperiod.' J. Ce11 Biol. 43(2):56a. 
12. Hymer, W. C. and W. Evans. 1970. Separation of rat anterior pituitary cells by sedimentation at unit gravity. Fed. Proc. $29(2): 472$.

13. Davis, J. and W. C. Hymer. 1970. Effects of castration and hypothalamic extract on protein synthesis in rat anterior pituitaries in vitro. Am. Soc. Zool. 10:300.

14. Hymer, W. C. and W. Evans. 1970. Protein synthesis in rat anterior pituitary cells separated by sedimentation at unit gravity. J. Cell Biol. 47(2):94a.

15. Mastro, A., and W. C. Hymer. 1970. DNA synthesis by isolated rat antertor pituitary gland nuclei. Amer. Zool. 10, 507.

16. Hymer, W. C., G. Snyder and J. Kraicer.. 1971. Divalent Cations and Growth Hormone Synthesis. J. Cell Biol., p. 134.

17. G. Snyder and W. C. Hymer. 1971. Divalent Cations and Growth Hormone Synthesis. 11, 656 .

18. W. C. Hymer, J. Kraicer and L. Glen. 1972. Effects of Dibutyry1 Cyclic AMP on dissociated Cells from the Rat Adenohypophysis. Canadian Physiology Meetings, Jan.

19. W. C. Hymer, J. Kraicer and J. Haskill. 1972. Purification of somatotrophs from the rat adenohypophysis by velocity and density gradient centrifugation. Fed. Proceedings, 31, 235.

20. W. C. Hymer, S. A. Bencoome, J. Kraicer and J. Haskill. 1972. Ultrastructural Characteristics of dissociated and separated rat adenohypophysial cells. Canad. Fed. Meetings, 15, 713.

21. W. C. Hymer and J. Kraicer. 1972. Growth hormone content of somatotrophs separated from the rat adenohypophysis. To be presented at the Amer. Physiol. Soc. fall meetings.

c. Submitted for publication.

22. A. Mastro and W. C. Hymer. 1972. DNA Polymerase activity in anterior pituitary glands of male rats: effects of age and estrone treatment. Biochem. Biophys. Acta.

D. Manuscripts and thesis material in preparation.

23. Davis - MS and results section $\mathrm{Ph} . \mathrm{D}$. thesis. (AEC reports 25 and 26)

24. Augustine - RNA polymerase. (AEC report 27) 
25. Snyder - MS thesis. (AEC report 28)

26. W. C. Hymer, Chapter in "Blological U1trastructure in the Pituitary," ed. M. G. Farquhar, F. Hagneau and A. Dalton (Academic Press). Cell Separation: A new approach to the study of pituitary cell function. (To be published at the end of next year). 